\title{
Controlling the effects of stress and seismicity in a sublevel caving operation
}

\author{
HCJ Esterhuizen Ernest Henry Mining, Australia
}

\begin{abstract}
The Ernest Henry mine (EHM) in Queensland, Australia is developed to a depth of just over $1 \mathrm{~km}$, and current active production cave levels have reached a depth of $730 \mathrm{~m}$. Caving started just below the pit floor at a depth of $535 \mathrm{~m}$, and is progressing deeper. The impact of stress and seismicity with increasing depth requires ongoing review and re-assessment of established practices and standards, and the implementation of new measures where required. Adverse effects of stress and the associated seismicity can have a significant impact on the safety, production and morale at a mine site. At EHM, an inclined sublevel caving operation, the geometry of the orebody and increasing depth provides for some interesting stress and seismic impacts, which are actively monitored and assessed. This paper outlines some of the observed rock mass responses, the impacts these had, and ongoing measures implemented to provide stability in an increasingly challenging environment.
\end{abstract}

Keywords: sublevel caving, stress, seismicity

\section{Introduction}

Ernest Henry mine (EHM) is a copper-gold operation situated in northwest Queensland, Australia (Figure 1). The iron oxide copper-gold deposit was discovered in 1991 through airborne geophysics. It is owned and operated by Glencore, with Evolution Mining also having a financial interest in the operation. The EHM sublevel cave is situated directly underneath the EHM open pit. Open pit mining finished in late 2011.

The operation is an established caving operation in full production, with current annual ore production of $6.8 \mathrm{Mt}$. All ore is hoisted via a dedicated ore hoisting shaft (Figure 2), whilst all man and material access is via a decline, with the portal situated within the open pit.

The EHM sublevel cave crown pillar was removed during the early mining of the cave, and the cave daylights in the open pit south wall (Figures 2 and 3). The orebody dips to the south at approximately $40^{\circ}$, which flattens out towards the bottom of the current planned mine (Figure 2). The sublevel cave footprint is currently around $215 \times 180 \mathrm{~m}$ for the main cave, with a small satellite lens being mined adjacent to the main cave measuring approximately $120 \times 45 \mathrm{~m}$. The orebody geometry and dip changes at increasing depth; in general the orebody becomes slightly narrower and longer.

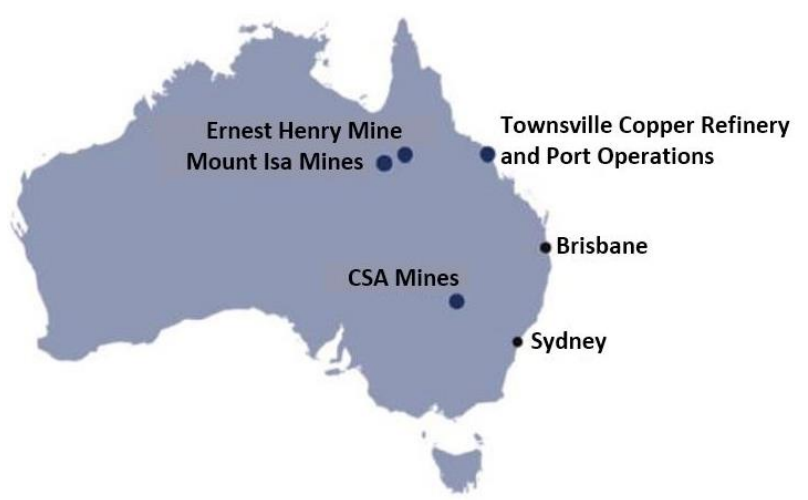

Figure 1 Location of Ernest Henry mine and other Glencore Australia copper operations 

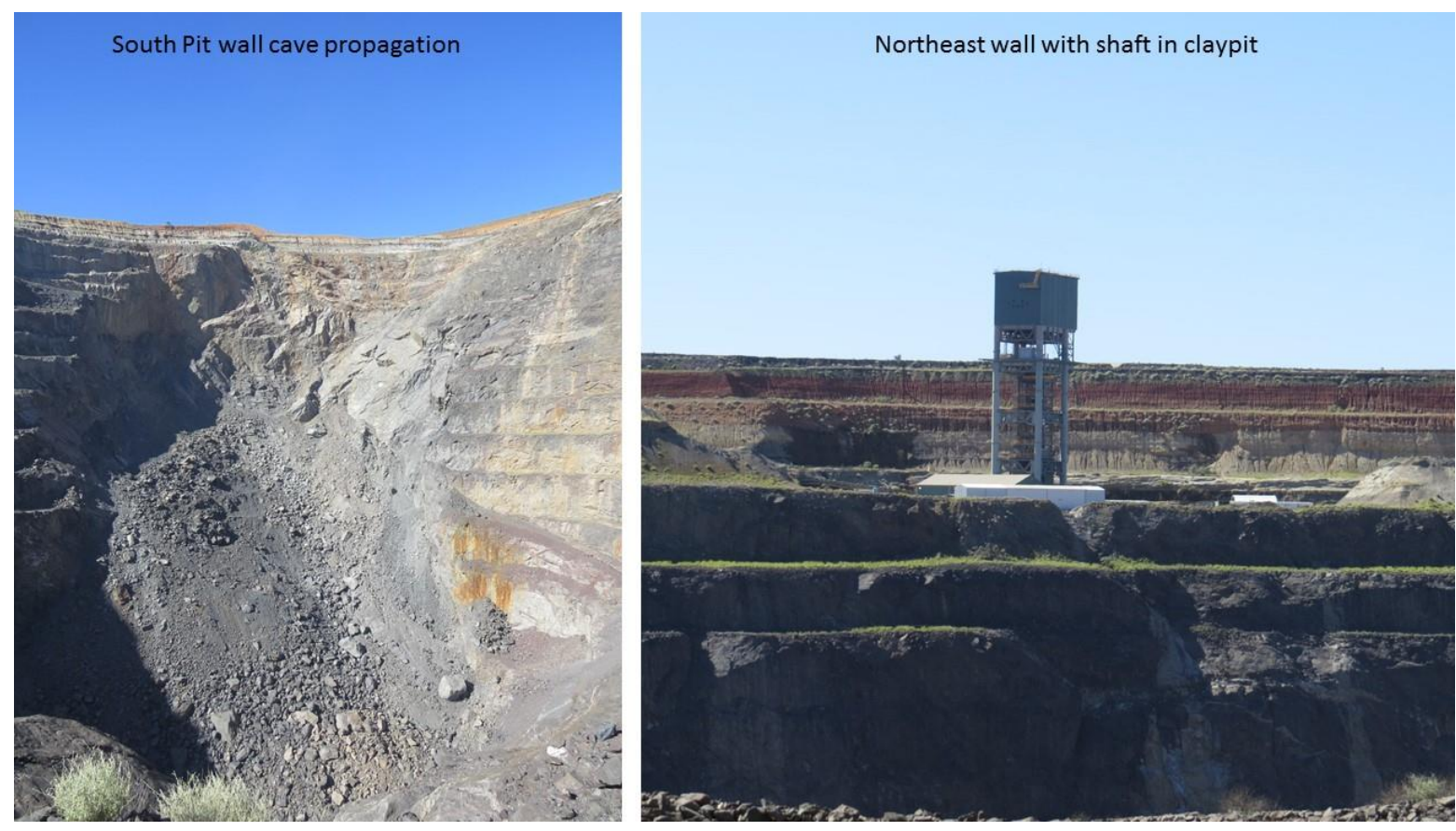

Figure 2 Ernest Henry mine south and northeast pit walls showing cave propagation zone on surface and shaft position in relation to the northeast pit wall

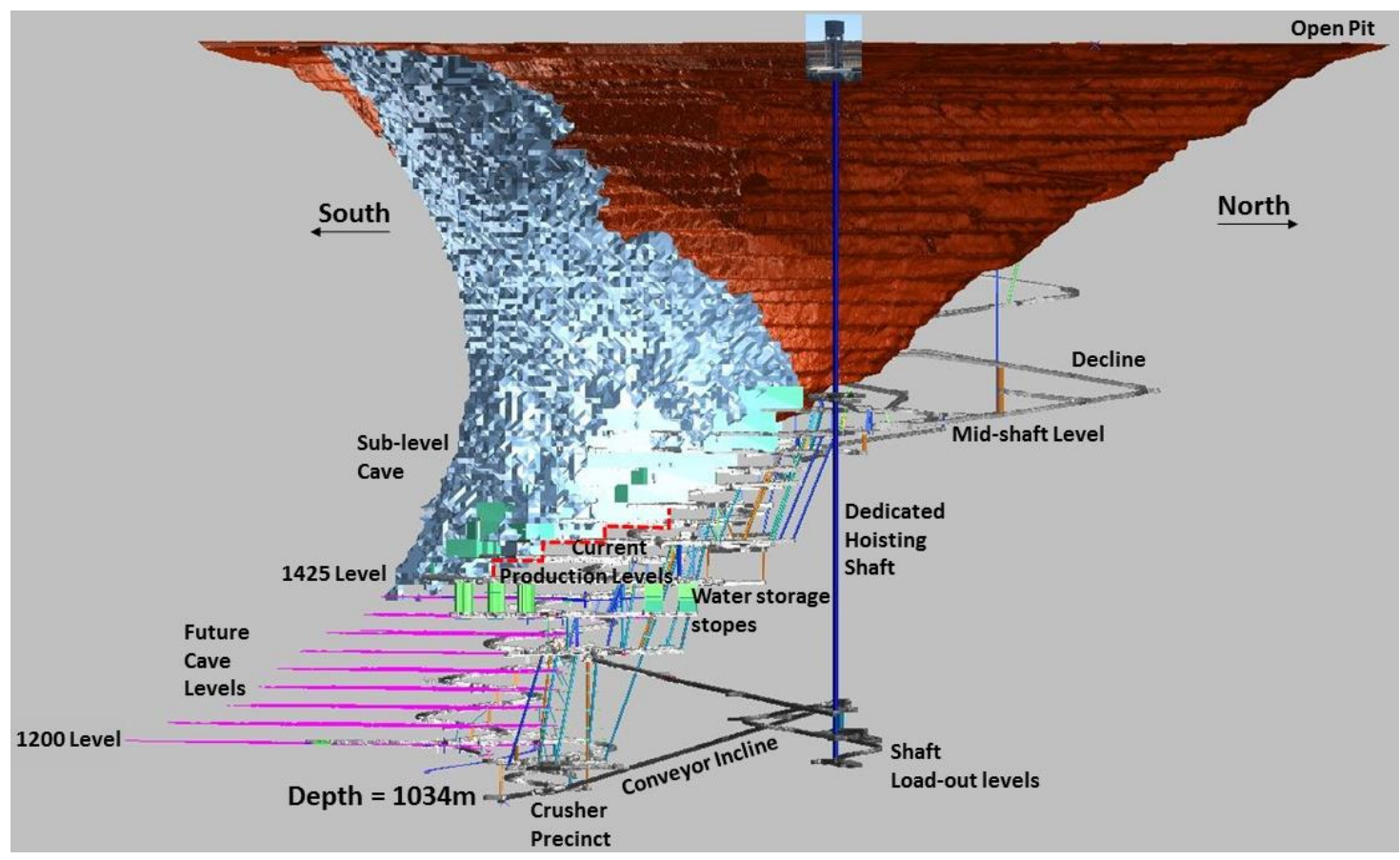

Figure 3 Perspective view of current Ernest Henry mine sublevel cave including open pit, infrastructure, future mining levels (purple lines) and current production levels (red dashed line)

\section{Geological setting}

Regionally, the EHM orebody is in the eastern portion of the Mount Isa block of the Eastern Fold Belt. Metasedimentary-metavolcanic rocks occur as three cover sequences. The orebody itself has no outcrop on surface and is overlain by 30-60 m of Mesozoic sediments. This cover consists of sand, shale and gravel. The pipe-like orebody is hosted in brecciated and altered intermediate volcanics. The orebody dips at $40^{\circ}$, is up to $250 \mathrm{~m}$ thick and $300 \mathrm{~m}$ wide, and is open at depth. Current resources are proven for up to a depth of approximately $1 \mathrm{~km}$. Figure 4 shows a long section of the orebody and rock types (from Miller 2017). 


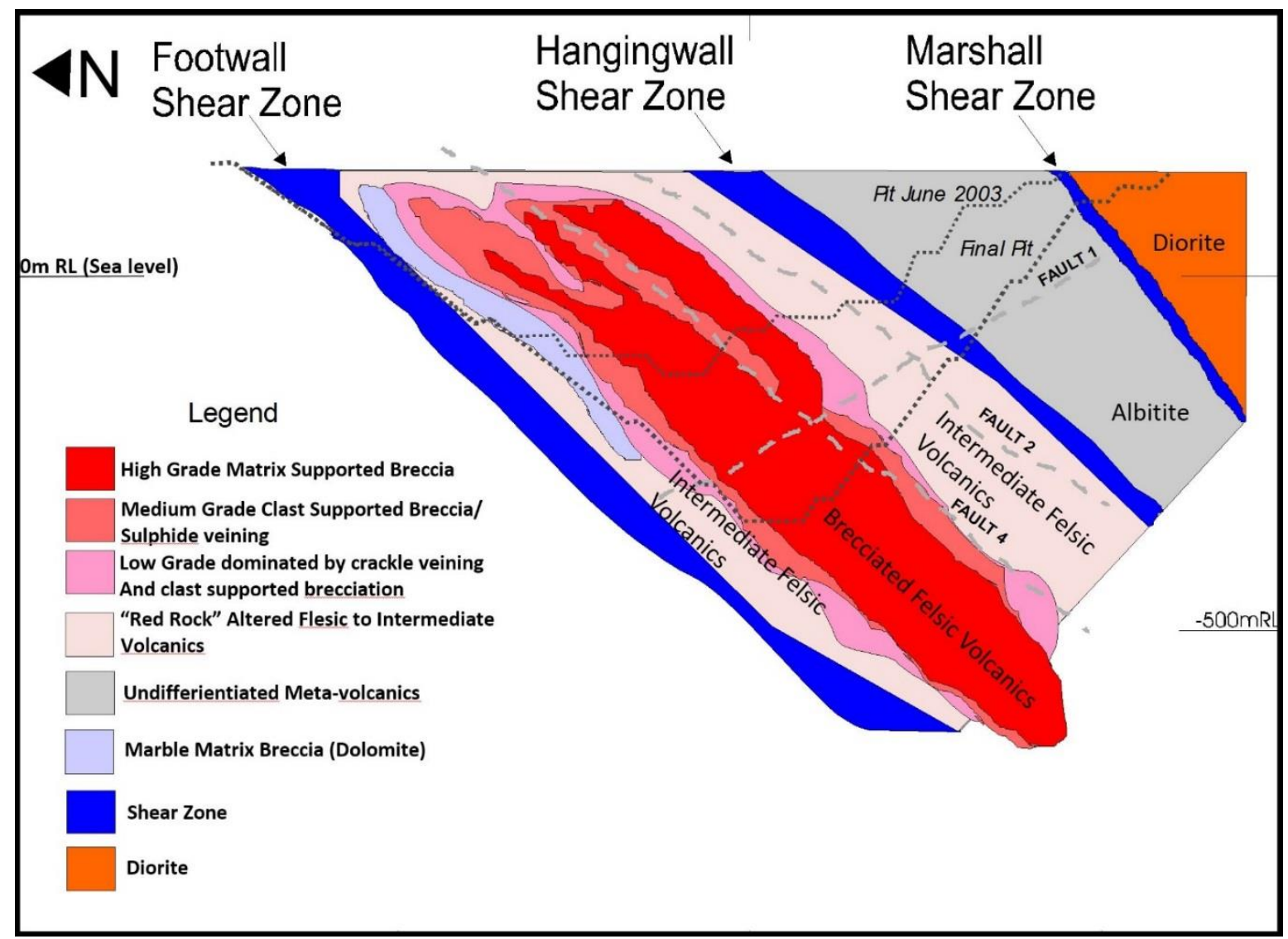

Figure 4

Ernest Henry mine geological section showing main rock mass types and structures

Below 1,525 mRL, the orebody splits into two distinct zones; the main cave zone and the southeast (SE) lens zone. These are separated by a weak foliated interlens pillar, and the SE lens itself is structurally more complex compared to the main cave. Figure 5 shows a section view through the EHM orebody, illustrating the above.

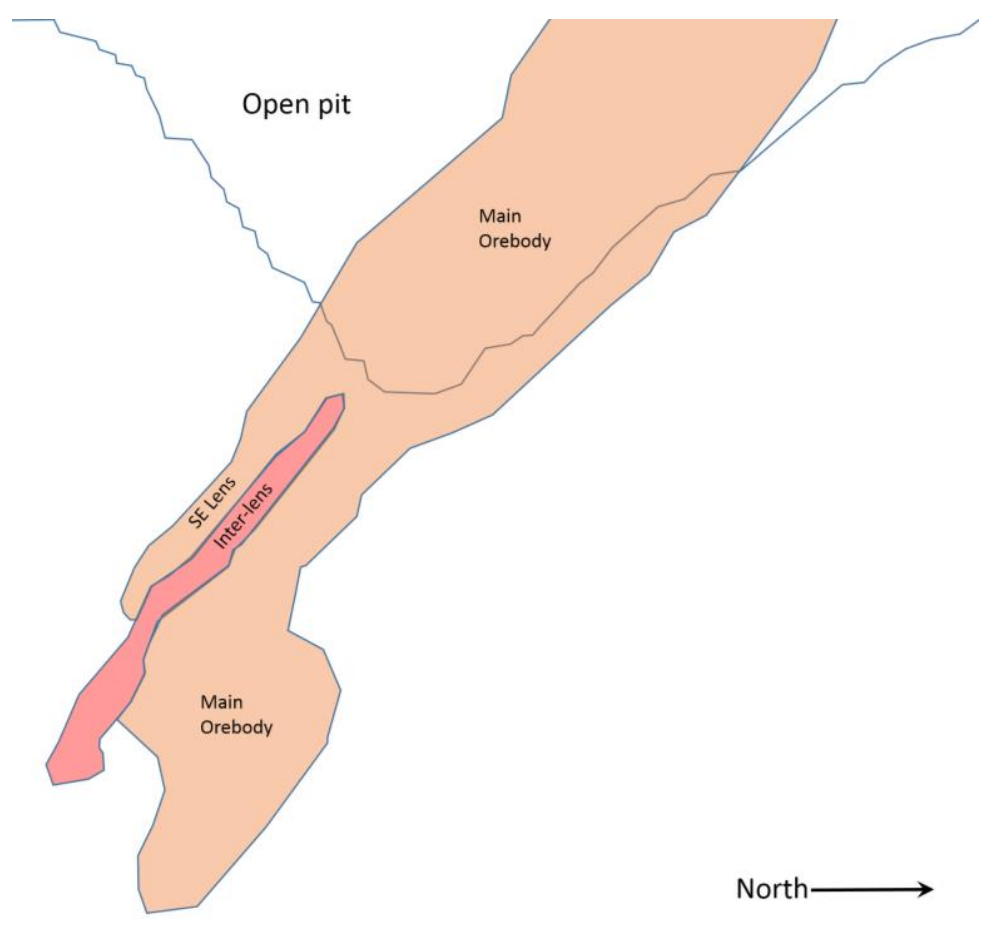

Figure 5 Ernest Henry mine long section showing the orebody split into the main orebody and SE lens 
The primary copper mineralisation is chalcopyrite. Some of the main rock types at EHM include the mineralised high-grade brecciated felsic volcanics (FV2), clast and matrix supported felsic volcanics in the footwall and hanging wall (FV1 and FV2) of the high-grade core, porphyritic intermediate volcanics (IV), fine grained albitite (FGAB), coarse grained albitite (CGAB) and diorite (Di).

Several prominent fault structures are present (Figure 6), mainly surrounding the orebody, except for one major fault that cuts through the orebody on the deeper levels. Apart from contributing to seismic activity, the faults also control the boundaries of different water zones within the mine. Several intermediate structures cut through the orebody.

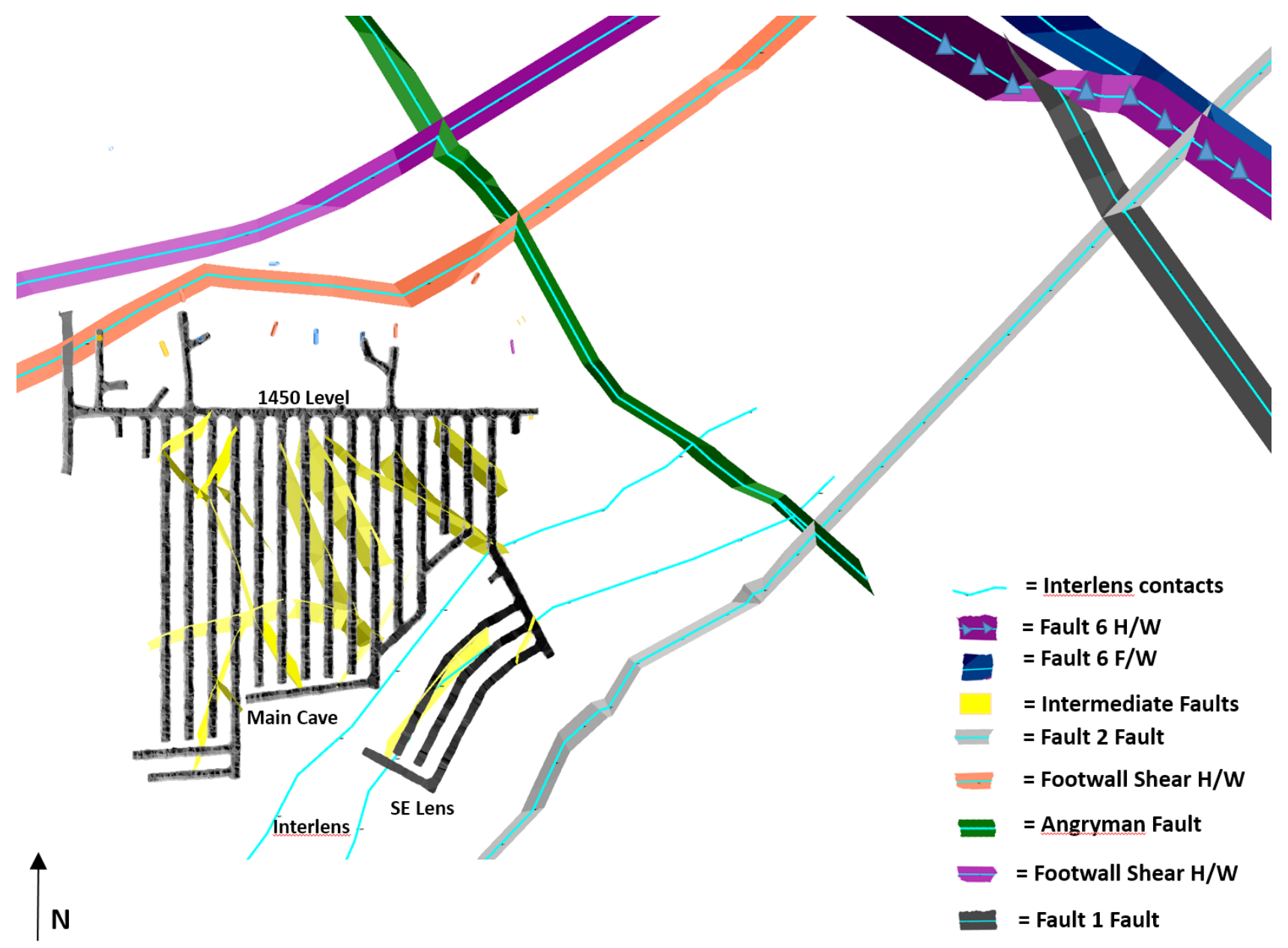

Figure 6 Ernest Henry mine faults 


\section{Geomechanical setting}

The geomechanical conditions influencing the mining areas at EHM can be broken down into six distinct domains based on the rock mass response and behaviour. See Table 1 for a short summary of these, and Figure 7 for the domain locations.

\section{Table 1 Ernest Henry mine geotechnical domains}

\begin{tabular}{ll}
\hline Domain & Summary of behaviour/rock mass response \\
\hline Hanging wall step-outs & $\begin{array}{l}\text { Good-quality rock mass conditions. Higher stress levels, increased seismic } \\
\text { frequency and magnitude of moderate sized events, very little } \\
\text { deformation damage. }\end{array}$ \\
Main cave & Good-quality rock mass conditions. Reduced stress levels, reduced \\
& significant seismic event frequency, seismic events focused on structures, \\
& damage at brows including wedge/layer separation, bagging of fractured \\
& material, and shear displacement on structures. Rock type is mainly felsic \\
& volcanics (FV, FV1 and FV2). FV2 is foliated, FV more massive and FV1 is \\
& characterised by veining. \\
SE lens orebody & Moderate to weak quality rock mass. Higher stress levels, increased \\
& seismic frequency and magnitude of moderate to large-sized events, high \\
& levels of structural deformation, high levels of ground support loading, \\
bulking and shearing. Behaves 'softer'. Higher water inflow. Rock type is & mainly FV1, and on the contact with the interlens contains high levels of \\
foliated schist. & \\
Good-quality rock mass, mainly FV1, with some FV2. Higher stress levels, & increased seismic frequency (especially large-sized events), very little \\
deformation damage, behaves brittle, large events sometimes focused \\
on intermediate-sized faults.
\end{tabular}



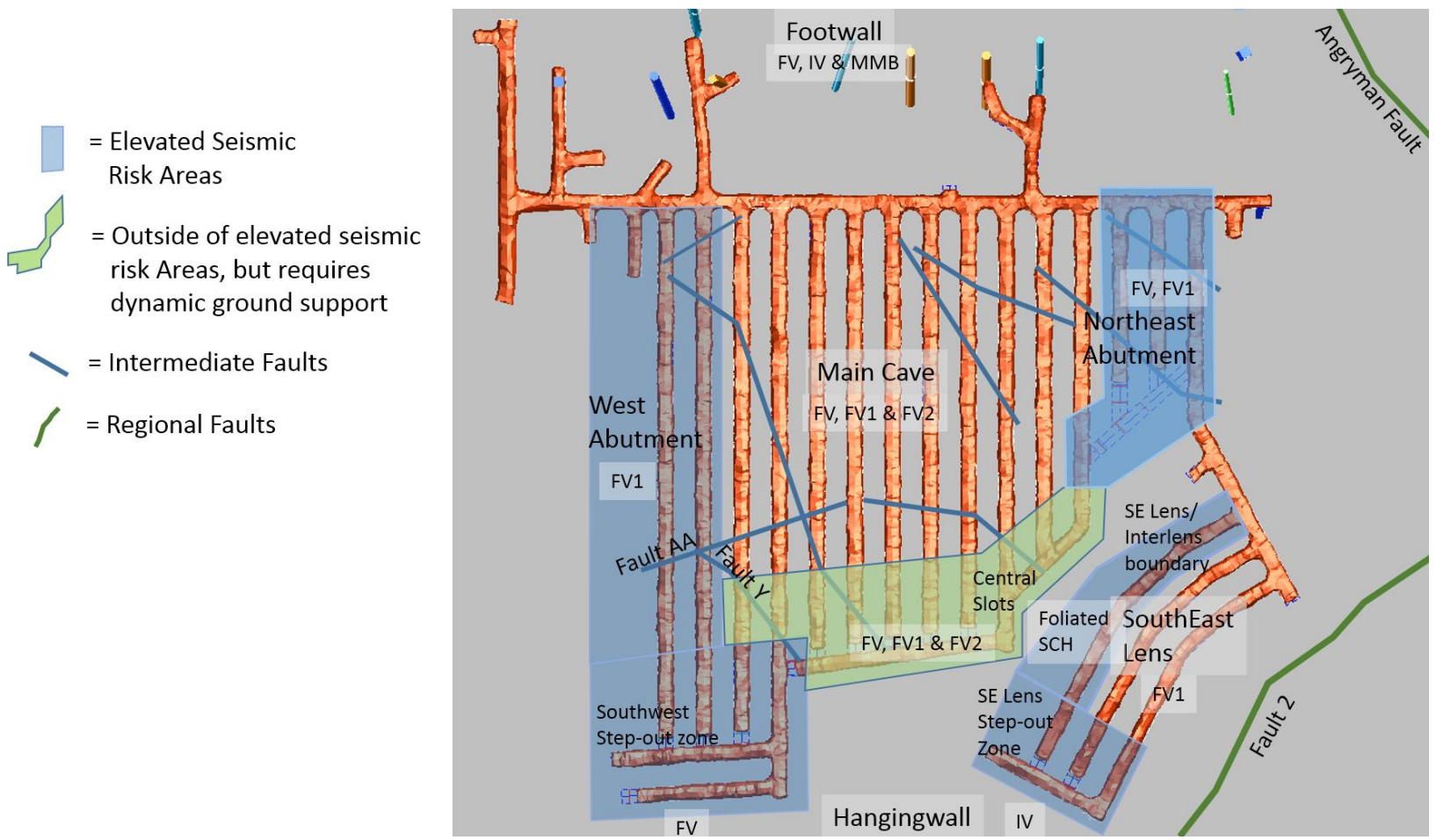

Figure 7 Ernest Henry mine seismic risk areas, domains and rock mass types

Table 2 contains a summary of the rock mass properties for EHM, and Table 3 shows the in situ stress regime. Ernest Henry mine has a flat-dipping major principle stress. The k-ratio $\left(\sigma_{h} / \sigma_{v}\right)$ is approximately two.

The $\sigma_{1}$ orientation is almost perpendicular to the orebody's dip direction, and the dip direction for F2. Sympathetic smaller structures called the F2 parallel structures and the F2 perpendicular structures traverse through the orebody, some of which is included in the mine's intermediate fault model.

Due to the relatively shallow dip of the EHM orebody, each new level steps out from under the cave into the high-stress abutment. This is called the step-out zone.

Table 2 Ernest Henry mine rock mass properties

\begin{tabular}{llllll}
\hline Rock type & $\begin{array}{l}\text { Uniaxial } \\
\text { compressive } \\
\text { stress (MPa) }\end{array}$ & $\begin{array}{l}\text { Young's } \\
\text { modulus } \\
\text { (GPa) }\end{array}$ & $\begin{array}{l}\text { Indirect } \\
\text { tensile } \\
\text { strength }\end{array}$ & $\begin{array}{l}\text { Poisson's } \\
\text { ratio }\end{array}$ & $\begin{array}{l}\text { Typical rock } \\
\text { quality } \\
\text { designation }\end{array}$ \\
\hline Albitite (FGAB) & 105 & 54 & 8 & 0.2 & 69 \\
Diorite & 103 & 42 & 10 & - & 78 \\
Schist & 101 & 42 & - & 0.3 & 75 \\
Felsic volcanics (FV1) & 129 & 46 & 7.5 & 0.3 & 89 \\
Felsic volcanics (FV2) & 144 & 45 & - & 0.3 & 89 \\
Porphyritic intermediate & 115 & 52 & 10 & 0.4 & 80 \\
volcanics (IV) & & & & & \\
Hanging wall shear zone (HWSZ) & 103 & 62 & 11 & 0.3 & $20-60$ \\
Footwall shear zone (FWSZ) & 124.5 & 54 & 8.5 & 0.2 & $20-60$ \\
\hline
\end{tabular}


Table 3 Ernest Henry mine in situ stress regime

\begin{tabular}{llll}
\hline Component & Magnitude & Dip & Dip direction \\
\hline$\sigma_{1}$ & $0.051 \times$ depth & $11^{\circ}$ & $279^{\circ}$ \\
$\sigma_{2}$ & $0.035 \times$ depth & $58^{\circ}$ & $27^{\circ}$ \\
$\sigma_{3}$ & $0.022 \times$ depth & $30^{\circ}$ & $182^{\circ}$ \\
\hline
\end{tabular}

\section{$4 \quad$ Risk associated with stress and seismicity at Ernest Henry mine}

\subsection{Seismic zones at Ernest Henry mine}

Currently, EHM's seismic zones are well defined, and the timing of the onset of seismicity is well understood. The following zones are the elevated seismic risk zones:

- Southwest step-out zone.

- SE lens step-out zone.

- SE lens boundary with the interlens pillar.

- Seismic activity inside or outside of the above zones, associated with specific fault structures.

Figure 7 shows the location of the abovementioned seismic zones on one of the current production levels. These are basically replicated on each new level, adjusted for local geometry, as well as for expected changes on seismic response.

The seismic areas listed above behave differently due to structures, rock mass properties, geometry and sequence. Typically the west abutment is more competent with strong structures, whilst the SE lens boundary with the interlens behaves 'softer' due to weak foliation and adjacent geological contacts and faults. The adjacent interlens pillar itself contains schist with a uniaxial compressive strength 20 to $30 \%$ lower than the adjacent orebody rock types. Due to the higher levels of displacement and energy dissipated through deformation in the SE lens, the area experiences lower magnitude seismic events. The opposite occurs on the southwest step-out and abutment where the good quality rock mass and strong geological structures allow for less deformation and more strain energy build-up on structures, and energy can therefore be released through much larger seismic events.

The differences in seismic response in the southwest (SW) step-out and southeast lens are illustrated in the data for 1450 and 1475 Levels in Table 4. The maximum event size for the SW step-out is $1.6 \mathrm{M}_{\mathrm{L}}$, whilst for the SE lens step-out it is $0.7 \mathrm{ML}$. The response relates to the rock mass and structural properties being significantly different in the SE lens, compared to the main cave west abutment. The SE lens has been mined on four levels now, and a good understanding of the behaviour and ground support requirements have been developed.

Table 4 contains a summary of typical seismic parameters for the seismic areas. It is clear the seismic response varies across the different seismic areas. For example, the South step-out area on the western side of the orebody has a higher apparent stress, whilst the SE lens step-out has a lower apparent stress. The higher apparent stress in the west is indicative of higher stress levels and higher damage potential.

The values in Table 4 are in line with observed behaviour underground where the west step-out and abutment behave in a more brittle fashion with less deformation and more frequent larger magnitude events, whilst the SE step-out and interlens boundary drives show significantly higher deformation and damage, and less frequent large seismic events. The typical performance of these different areas is replicated with depth, i.e. the areas maintain their seismic characteristic on each deeper level, although the severity appears to be increasing. 
Table 4 Ernest Henry mine seismic areas parameters - May 2017 to May 2018

\begin{tabular}{|c|c|c|c|c|c|}
\hline Seismic area & $\mathrm{X}_{\max }\left(\mathrm{M}_{\mathrm{L}}\right)$ & b-value & $\begin{array}{l}\text { Average } \\
E_{s} / E_{p} \text { ratio }\end{array}$ & $\begin{array}{l}\text { Average apparent } \\
\text { stress }(\mathrm{kPa})\end{array}$ & $\begin{array}{l}\text { Number of } \\
\text { events } \geq 0.5 \mathrm{M}_{\mathrm{L}}\end{array}$ \\
\hline $\begin{array}{l}\text { Southwest step-out } \\
\text { (1450 Level) }\end{array}$ & 1.6 & 0.71 & 7.12 & 9.98 & 9 \\
\hline $\begin{array}{l}\text { Southeast lens step-out } \\
\text { (1450 Level) }\end{array}$ & 0.7 & 0.65 & 5.5 & 5.14 & 1 \\
\hline $\begin{array}{l}\text { West abutment } \\
\text { (1475 Level) }\end{array}$ & -0.5 & 0.95 & 6.8 & 3.44 & 0 \\
\hline $\begin{array}{l}\text { Southeast lens boundary } \\
\text { (1475 Level) }\end{array}$ & 0.3 & 0.66 & 6.22 & 6.06 & 0 \\
\hline
\end{tabular}

Note: $\mathrm{mMin}$ was set to $-2.0 \mathrm{ML}$

\subsection{Seismic risk}

EHM historically experienced significant damaging seismic events, especially in the early years of the underground operation. Figure 8 shows the seismic event size distribution for the whole of EHM for all time. The b-value overall is 0.85 .

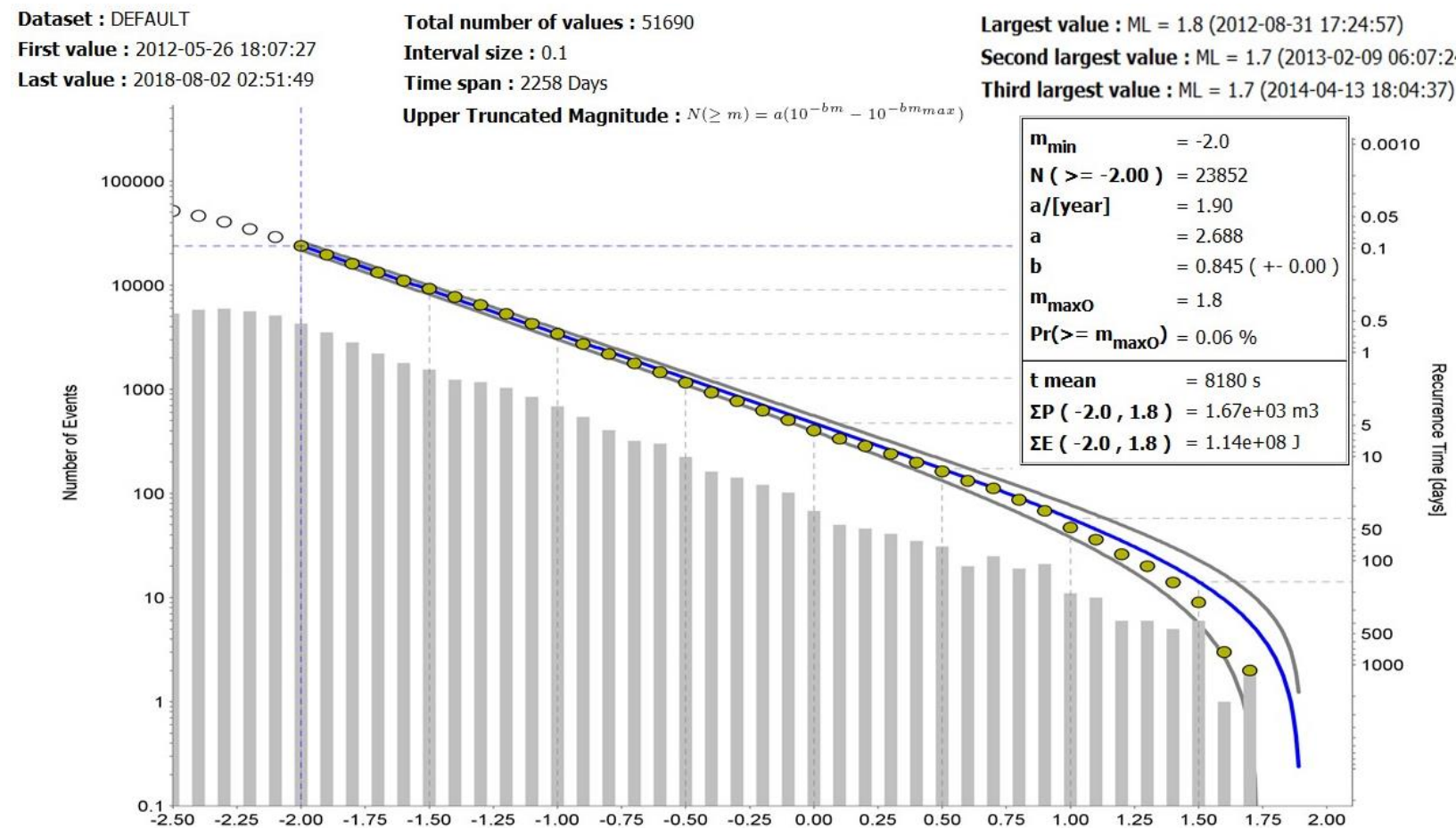

Figure 8 Ernest Henry mine upper truncated magnitude size distribution - all events, all time

Table 5 illustrates the change in seismic response year-on-year. There was a steady reduction in the maximum magnitude of seismic events, as well as a steady increase in the b-value. The graph shown in Figure 9 shows that the 2017/2018 year proved to be a turning point with an increase in the magnitude and number of events recorded. This coincides with production mining past the $700 \mathrm{~m}$ depth. 
Table 5 EHM - summary of seismic events per year with associated seismic parameters**

\begin{tabular}{|c|c|c|c|c|c|c|}
\hline Year & Period & $\begin{array}{l}\text { Number } \\
\text { of events }\end{array}$ & $\begin{array}{l}\text { No. of events } \\
\geq 1 M_{L}\end{array}$ & b-value & $\mathrm{X}_{\max }\left(\mathrm{M}_{\mathrm{L}}\right)$ & $\begin{array}{l}X_{\max } \text { distance to } \\
\text { opening }(\mathrm{m})\end{array}$ \\
\hline $2012 / 13$ & $\begin{array}{l}26 / 05 / 2012 \text { to } \\
31 / 05 / 2013\end{array}$ & 3,287 & 13 & 0.62 & 1.8 & 38 \\
\hline $2013 / 14$ & $\begin{array}{l}01 / 06 / 2013 \text { to } \\
31 / 05 / 2014\end{array}$ & 2,921 & 6 & 0.79 & 1.7 & 3 \\
\hline $2014 / 15$ & $\begin{array}{l}01 / 06 / 2014 \text { to } \\
31 / 05 / 2015\end{array}$ & 5,647 & 5 & 0.77 & 1.5 & 11 \\
\hline $2015 / 16$ & $\begin{array}{l}01 / 06 / 2015 \text { to } \\
31 / 05 / 2016\end{array}$ & 2,900 & 7 & 0.93 & 1.5 & 18 \\
\hline $2016 / 17$ & $\begin{array}{l}01 / 06 / 2016 \text { to } \\
31 / 05 / 2017\end{array}$ & 3,015 & 4 & 1 & 1.3 & 35 \\
\hline $2017 / 18$ & $\begin{array}{l}01 / 06 / 2017 \text { to } \\
31 / 05 / 2018\end{array}$ & 5,088 & 8 & 1.05 & 1.6 & 9 \\
\hline
\end{tabular}

** Filtered, $\mathrm{M}_{\mathrm{L}} \geq-2 ; 8+$ triggered sensors

The steady improvement in b-value is a reflection of an initial drop in the number of large events per year. In $2017 / 2018$, the large event rate started to increase again, but there was also a significant increase in the overall number of events for the year. The result is a slightly higher b-value for 2017/2018. The higher b-value in 2017/2018 does not reflect the increase in risk associated with the increase number of large events. In the EHM case, the b-value will be influenced by where mining is predominantly occurring during that year, in step-out zones, or under the main cave.

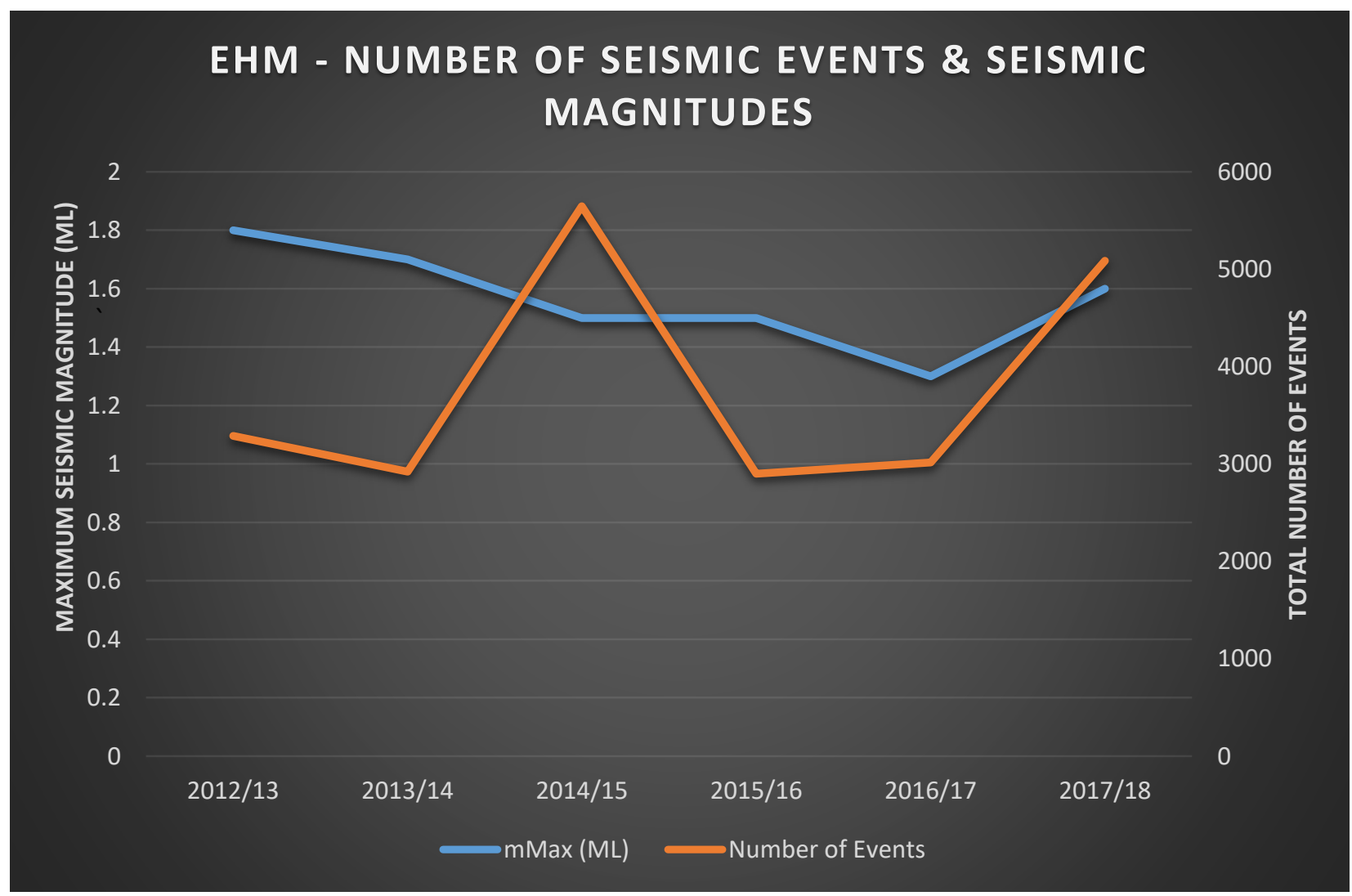

Figure 9 Ernest Henry mine trends for maximum magnitude and number of events recorded (filtered, as per Table 5) 
Figure 10 shows that the b-value per annum for EHM has been steadily increasing since 2013/2014 to above 1 in the $2017 / 2018$ year.

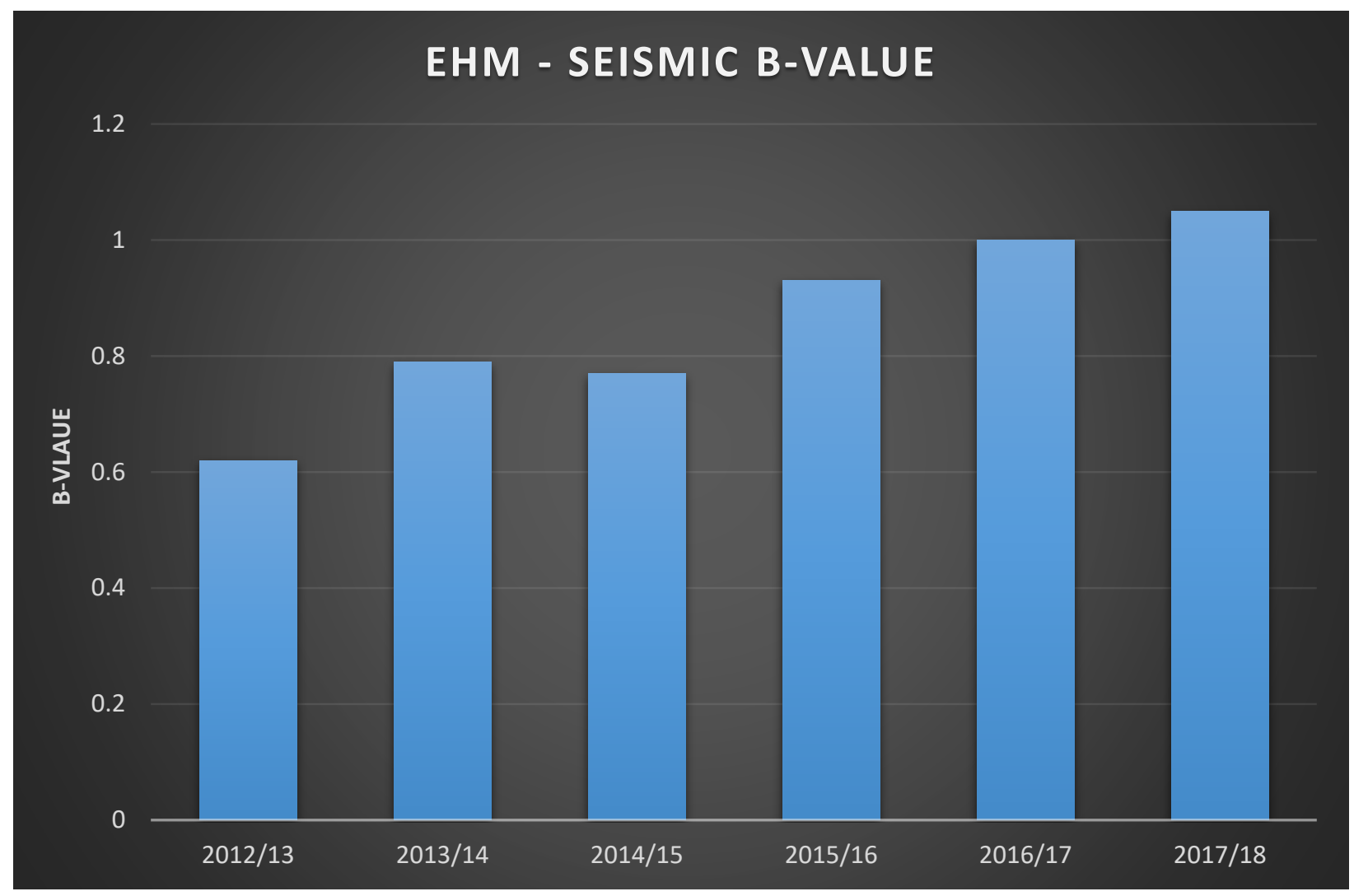

Figure 10 Ernest Henry mine b-value trend - increasing to its highest level in 2017/2018. Obtained from using an upper truncated magnitude size distribution

In the $2017 / 2018$ year, both the $b$-value and the number of large events $\left(\geq 1 M_{L}\right)$ increased. The increasing depth at EHM where the production level mining is now occurring at depths exceeding $700 \mathrm{~m}$ is starting to affect the volume of seismic events and the magnitude levels recorded, both recording a significant increase this year.

The seismic hazard scale (SHS), SHS $\approx \log _{10}(\mathrm{~N}) / b+\mathrm{M}_{\mathrm{L}}$, documented by Hudyma and Potvin (2004) provides a methodology to assess seismic hazard. $\mathrm{M}_{\mathrm{L}}=$ local magnitude of given event, $\mathrm{N}=$ number of events with a magnitude of at least $\mathrm{M}_{\mathrm{L}}$, and $\mathrm{b}=$ slope of the relationship. Using a potentially damaging seismic event magnitude of $1.5 \mathrm{ML}$, EHM calculates a SHS $\approx 2.65$, which classify the relative seismic hazard as high. Using $\mathrm{X}_{\max }=1.8 \mathrm{ML}$ the SHS $\approx 1.8$. Figure 11 plots EHM's SHS on the same graph as the 2002 Australian Mine Seismicity Survey results documented by Hudyma and Potvin (2004), giving some perspective to where EHM sits in relation to seismic hazard.

Using the rockburst damage potential (RDP) methodology documented by Heal et al. (2006), EHM falls within the $\mathrm{R} 2$ range of the expected rockburst damage scale (RDS), based on a $1.8 \mathrm{M}_{\mathrm{L}}$ event at a distance of $10 \mathrm{~m}$ from the excavation. Overall, the data indicates a moderate seismic risk at EHM, which is in line with what is experienced in practice onsite. 


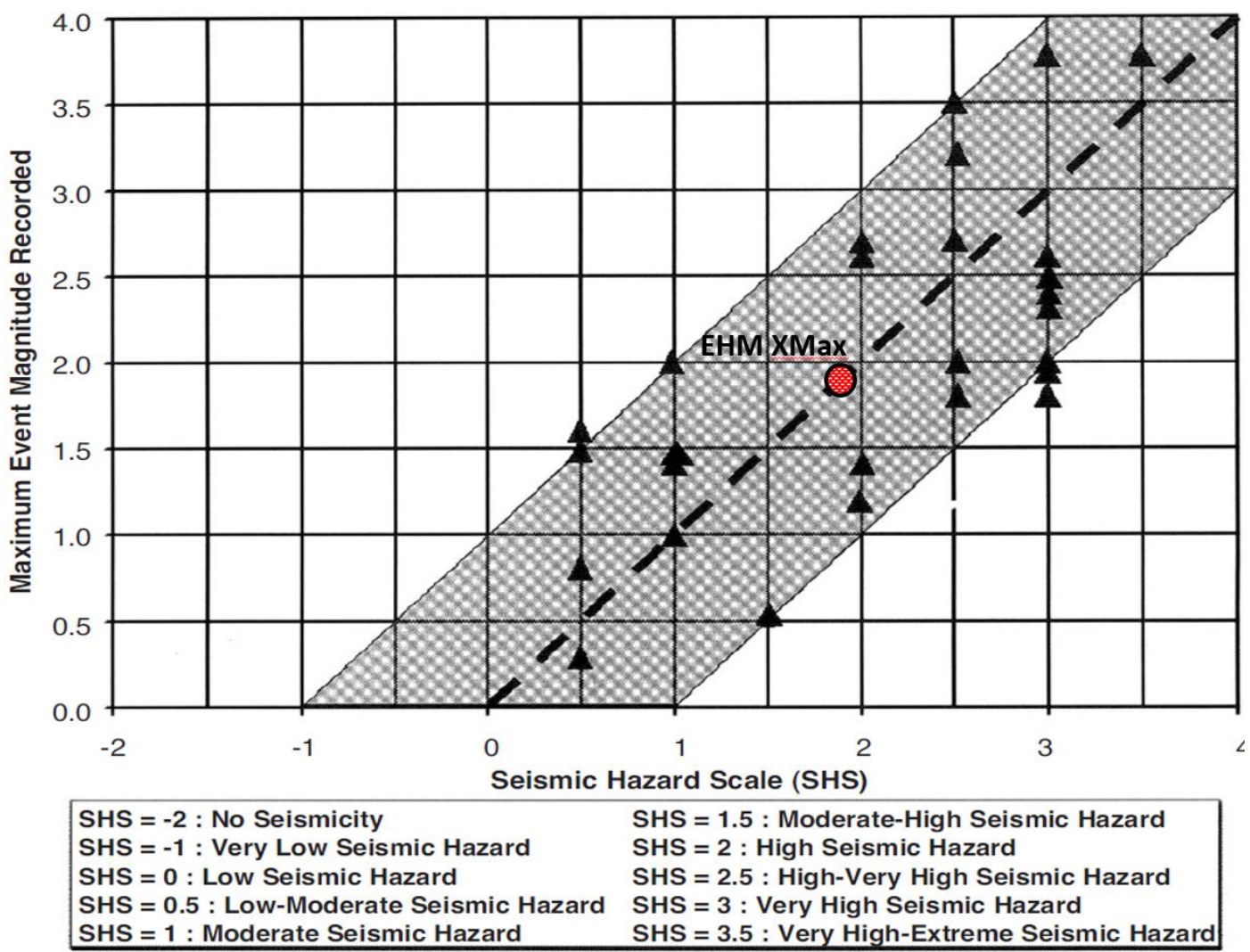

Figure 11 Ernest Henry mine's maximum event magnitude and SHS classification scale

\subsection{Stress and displacement}

Stress and displacement at EHM is controlled by the in situ stress, induced stress from the cave, geological structures and the local rock mass properties. Stress conditions can vary significantly depending on the position of the cave front, i.e. in high-stress step-out, or under the main cave. Due to the nature of the mining method, ore drives at EHM undergo several cycles of stress change. In terms of major principal stress values $\left(\sigma_{1}\right)$ elastically modelled, typical values range from 12 to $140 \mathrm{MPa}$ on a production level. Non-linear modelling results vary between -1.5 and $70 \mathrm{MPa}$, with some pillar areas exceeding $100 \mathrm{MPa}$. See Figure 12 for a non-linear plot of $\sigma_{1}$. Non-linear modelling was conducted by Beck Engineering (2017), providing result files for analysis and interpretation by onsite geotechnical engineers.

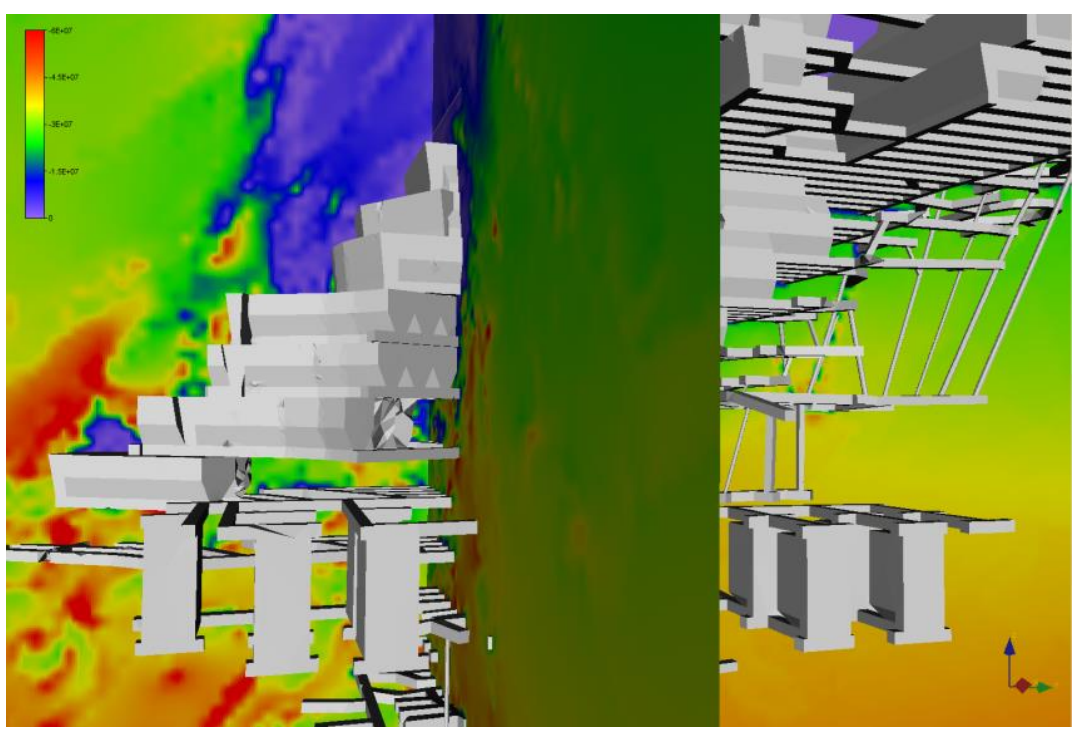

Figure 12 Non-linear stress modelling results - perspective view showing $\sigma_{1}(\mathrm{~Pa})$ 
Due to the relatively good quality rock mass throughout EHM, the excavation wall deformation rates are very low, as is dilation. The RQD typically varies between 80 and 100 within the orebody and immediate boundaries, except close to some geological structures (Figure 13). The exception is the SE lens, and specifically where the interlens contact and adjacent foliation is present on the SE lens boundary. Very significant dilation and damage due to plastic strain occur in this area (Figure 14).

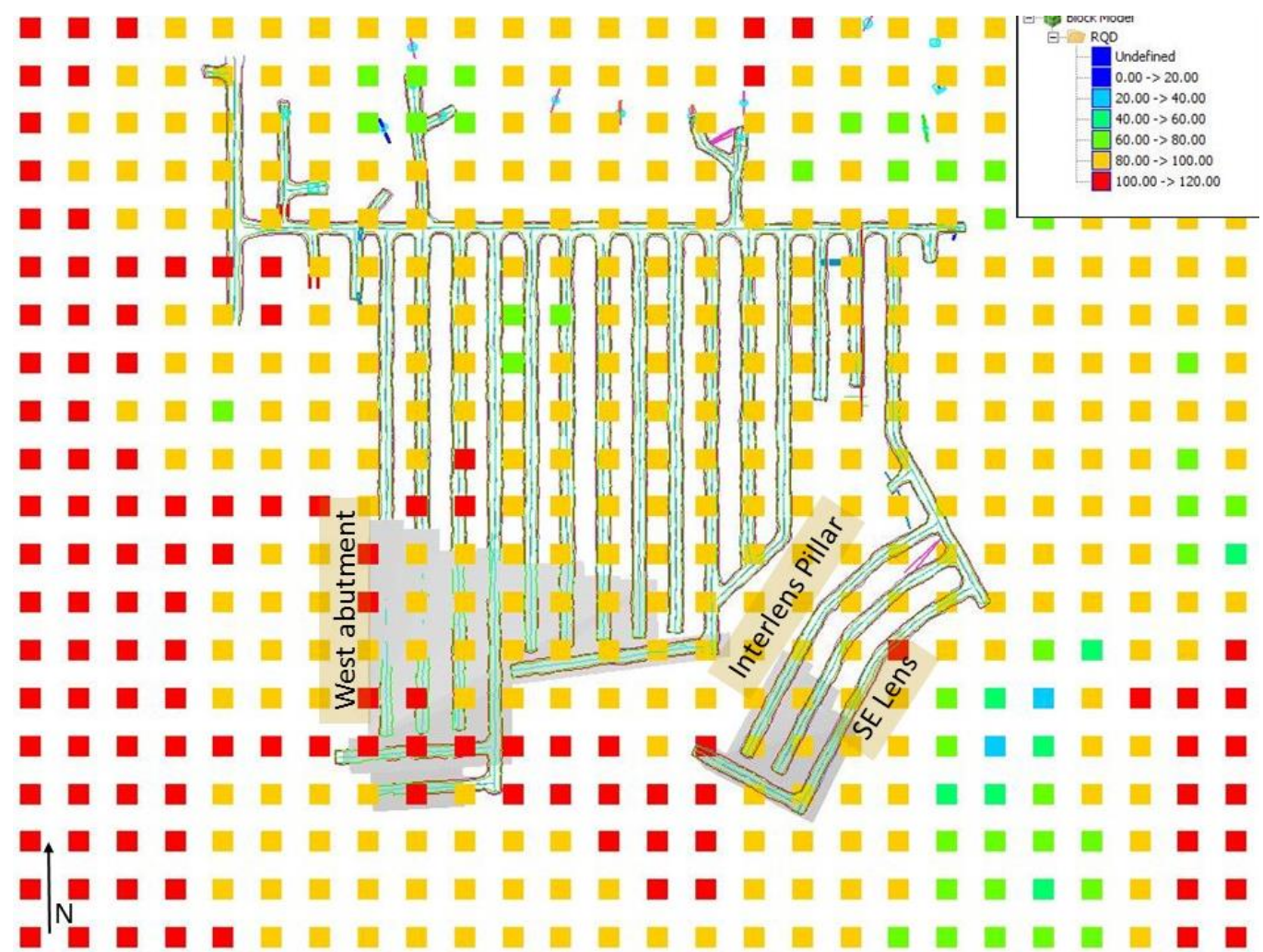

Figure 13 RQD values on a typical level. Note higher values in the west abutment. The lower values to the east of the SE lens are associated with the Fault 2 regional structure

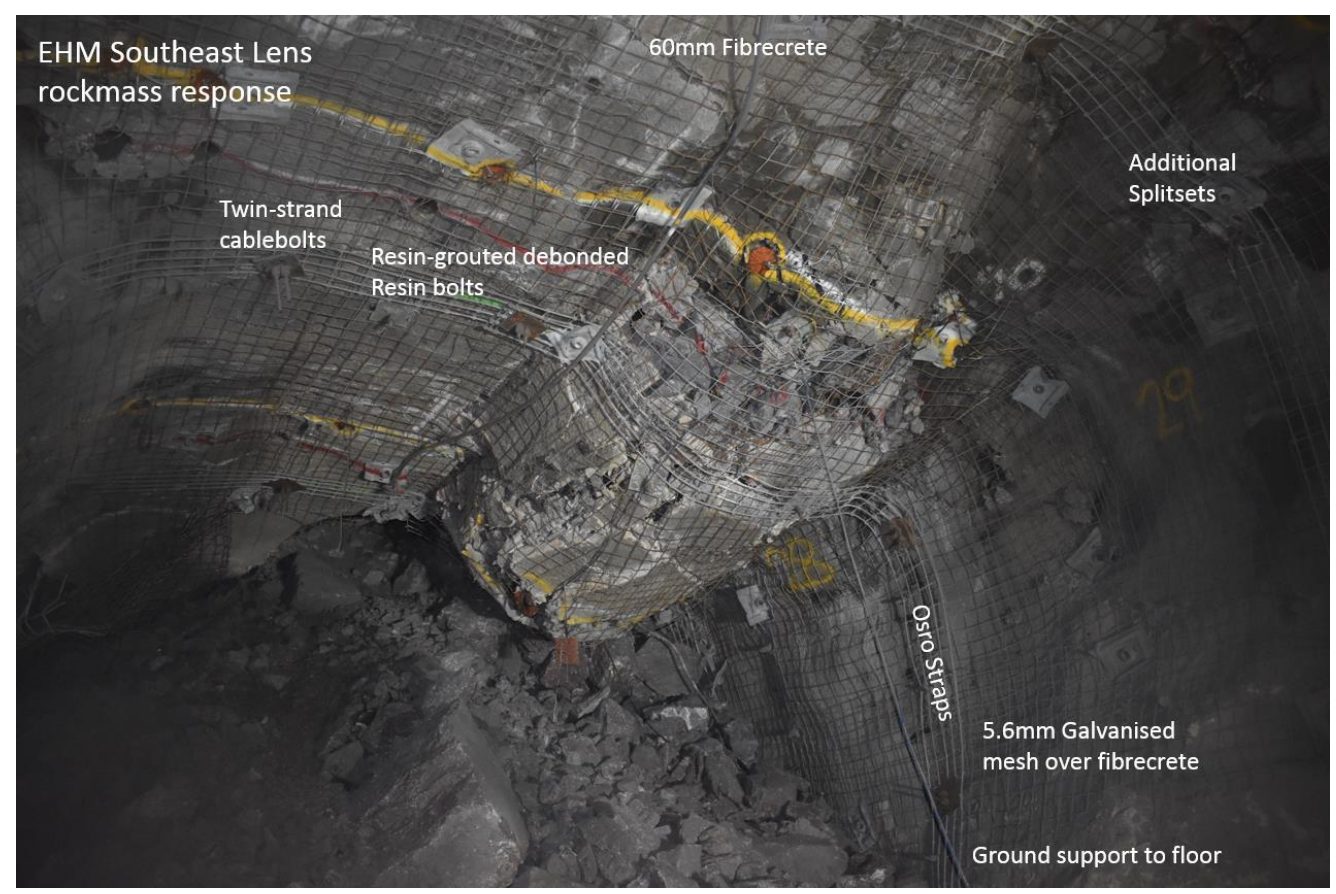

Figure 14 Ernest Henry mine SE lens rock mass response - significant displacement on geological structures and fractured formed, dilation of fractured material, and containment in surface support 


\section{$5 \quad$ Impact of stress and seismicity}

The impacts of seismic events and excessive rock mass deformation at any mine, including EHM, includes:

- Rockfalls with the potential to cause harm and damage to equipment.

- Potential loss in revenue due to lower tonnes and allocation of resources for remedial works.

- Increase in cost due to additional ground support required.

- Significant deformation can result in significant production hole re-drills required.

- Impacts on the mine schedule.

- Damage large enough with slow remedial works can result in a delay to advancing the cave front, which can have both an immediate impact on production, but also lengthy delays in getting the cave front fixed.

- Impact on the morale of personnel working in the area if they observe or experience adverse rock mass response.

Two of the more significant impacts, rockfalls and production delays, are described below. These have both safety and financial impacts, and the impacts listed above all relate to these two issues.

\subsection{Rockfalls}

Figure 15 shows there has been a good downwards trend in the rockfall rate per year; 2017 was an exception. The downward trend continues in 2018. Changes to installed primary and secondary ground support, sequencing, and discipline in identifying and addressing rock-related hazards contributed to this improvement. Each rockfall is investigated in detail, which includes cause analysis, exposure considerations, risk level determination, and actions to reduce the probability of future occurrences.

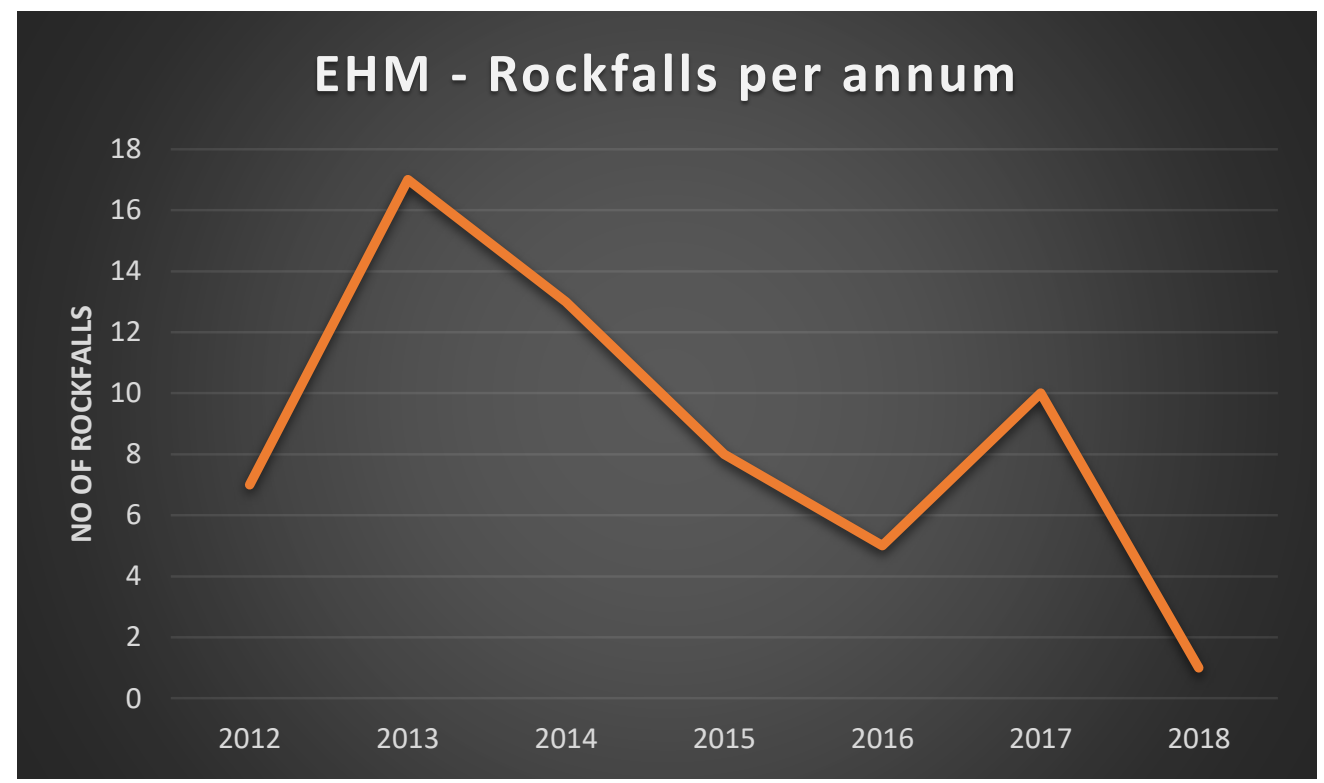

Figure 15 Ernest Henry mine reducing rockfall rate

\subsection{Production delays due to re-drills and rehabilitation}

- Clean-outs and re-drills are more prevalent in high-stress step-out zones and the SE lens.

- Up to two shifts of delays due to re-drills can be experienced per charging cycle.

- Whilst cleaning and re-drills are in progress, adjacent drives are also prevented from charging in order to maintain the lead/lags between drives. 
- Rehabilitation of rockfalls gets priority and is done immediately. EHM has flexibility in terms of available ore drives, and production can be shifted to other areas, which reduces the impact to the minimum if there are delays due to rehabilitation or re-drills.

- Areas identified as needing rehabilitation (includes non-rockfall areas) is prioritised and entered into a rehabilitation register. Areas that pose a risk to personnel and equipment are either fixed immediately or barricaded until they can be rehabilitated.

- Due to improvements made in ground support products and standards, rehabilitation at EHM has reduced significantly. Improvements include the use of thermally diffused galvanised rockbolts throughout the mine, all mesh changed to $5.6 \mathrm{~mm}$ galvanised mesh, and increased capacity in ground support where needed. Most of the current rehabilitation in the EHM rehabilitation register is for pro-active ground support upgrades and 'prehabilitation' works. Prehabilitation is upgrading ground support in areas where the historical ground support standards used are not deemed adequate and new support is installed to bring it to current standards.

\section{Measures implemented}

EHM has made several improvements over a number of years. These include both, improvements from learnings from incidents, as well as pro-active measures through analysis and anticipation of future requirements. There are too many to list; below are some of the key improvements:

- Introduced a $20^{\circ}$ west-biased cave front in reaction to a large seismic event in order to improve the angle of approach and loading of structures. This proved to be successful and is well maintained. Each level is reviewed at a weekly planning meeting with all stakeholders present.

- Introduced rules and approval systems around managing leads and lags between ore drives.

- All future levels are thoroughly assessed from a geotechnical perspective, and input given into the design, sequencing and scheduling of every cave level. All sequences are assessed and approved by the geotechnical department and any future changes require geotechnical approval. The focus is on pro-active identification of future needs and requirements.

- Perimeter-controlled blasting to limit damage to excavation walls.

- Horseshoe development profile in all high-stress/elevated seismic risk areas (Figure 16).

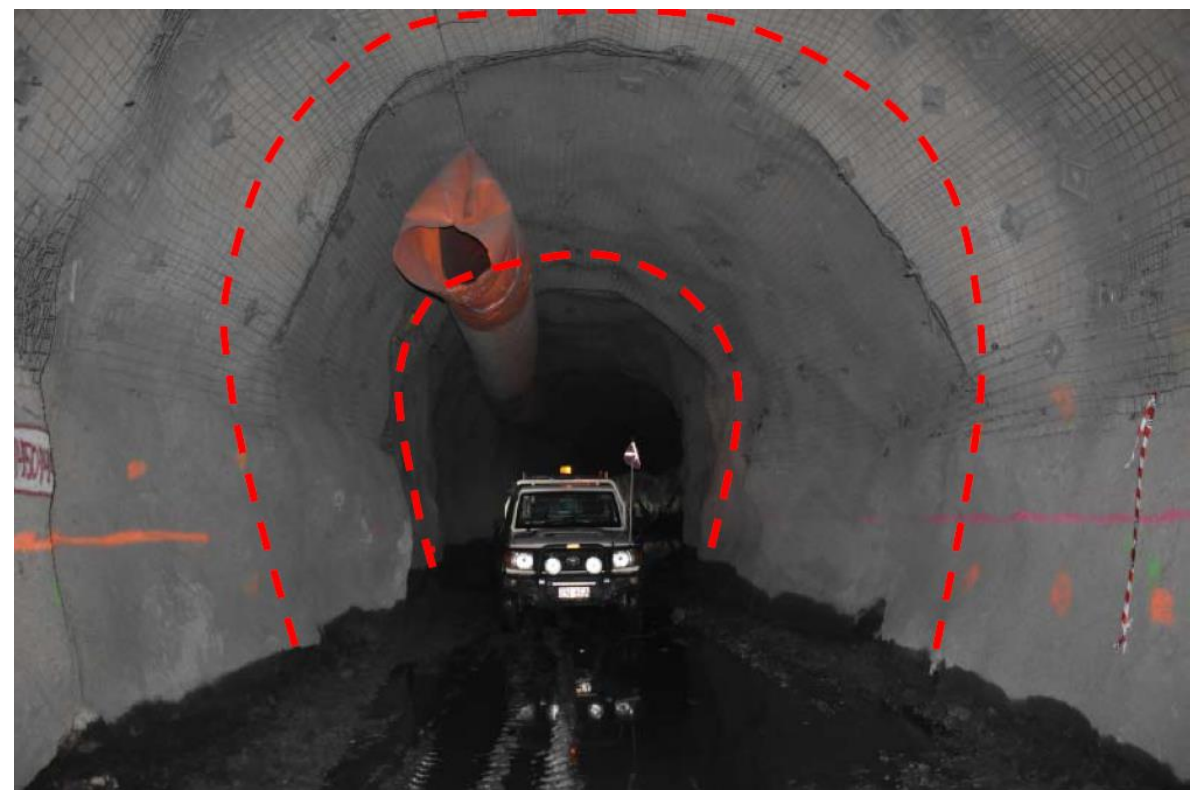

Figure 16 Horseshoe profile 
- Detailed seismic analysis, including daily seismic hazard assessments, weekly seismic reports and monthly seismic analysis. This is done by site personnel who develop a closer relationship with the rock mass through using the seismic data to assist in the understanding of the rock mass response for different areas of the mine.

- The daily seismic analysis includes a trigger action response plan (TARP) to guide action if needed, and a daily seismic analysis register where the assessment values are recorded and a hazard ranking calculated. Factors included in the daily analysis of areas of elevated seismic risk include cumulative apparent volume (CAV), log energy index (Log EI), daily seismic event rate, number of significant events in the last 24 hours, number of large seismic events recorded in the last 24 hours, and the peak ground velocity (PGV).

- The seismic TARP includes measures to withdraw people or extend exclusion times.

- Use of dynamic ground support in the form of de-bonded resin bolts. Rockbolts are integrated with strong surface support which may include $60 \mathrm{~mm}$ fibrecrete, $5.6 \mathrm{~mm}$ galvanised mesh, Osro straps, and twin strand cable bolts installed through the straps. The cable bolts have proven especially effective in the high-deformation SE lens on the 1450 Level.

- Ground support standards were upgraded and the sidewalls in areas of elevated seismic risk/high stress are supported down to the floor. No exposed sidewalls exist that can deteriorate or cause sidewall rockfalls.

- Each new level is re-assessed once developed, ground support upgrades are identified, and ground support upgraded prior to production where needed. There is good management support for ground support upgrades. Ground support upgrades have proven their worth in several instances where they prevented rockfalls from occurring.

- Face meshing standards and TARP for face meshing.

- Damage mapping, infrastructure inspections register, and detailed structural mapping of all drives include some of the other controls.

\section{Conclusion}

Ernest Henry mine has implemented several measures to improve the outcomes of the rock mass response to mining activities. These are the result of actively monitoring and analysing data, and proactively taking action. Measures implemented so far have added value to the business, and EHM will continue to work on continuous improvements.

\section{Acknowledgement}

The author acknowledges the management and personnel at Ernest Henry mine for their contribution in implementing and supporting the improvements described, especially the geotechnical department.

\section{References}

Beck Engineering 2017, data from non-linear modelling finite element numerical modelling conducted for Ernest Henry mine, Beck Engineering, Chatswood West.

Heal, D, Potvin, Y \& Hudyma, M 2006, 'Evaluating rockburst damage potential in underground mining', in DP Yale, SC Holtz, C Breeds \& U Ozbay (eds), Proceedings of the 41st US Symposium on Rock Mechanics, American Rock Mechanics Association, Alexandria.

Hudyma, M \& Potvin, Y 2004, 'Seismic hazard in Western Australian mines', Journal of The South African Institute of Mining and Metallurgy, vol. 104, no. 5, pp. 265-276.

Miller, B 2017, unpublished internal mine presentation on Ernest Henry mine geology, Ernest Henry Mining, Cloncurry. 
